\title{
A New Perspective on Transfer Policy: Are Community College Transfer Students Getting an Equitable Academic Experience at Small Private Colleges?
}

Sally E. Hyatt, Ph.D., Kutztown University of Pennsylvania

With the declining enrollment of the traditional college student, small private universities are increasingly attracting community college transfer students, yet community college transfer research invariably occurs at public universities. To provide a view from a private college, this qualitative study sought to describe how faculty perceived the community college transfer student experience at a small, nonprofit, private university. Using an ethnographic study design, twelve faculty were interviewed to describe the culture, the perception of the students' experiences with the university, and the institutional policies that applied to community college transfer students. Findings illustrated the potential for inequity within the academic experience between student types. Analysis of the interview data developed the following themes: a systematically distinct experience for community college transfer students, limited access to signature programs for community college transfer students, and the unmet needs of community college transfer students. These themes, gathered from a thematic data analysis, helped the researcher present a new perspective on transfer policy as well as implications to practice for campuses and future research recommendations centered on equity and academic policy.

Post-secondary enrollment in America has remained stagnant; however, private nonprofit colleges are increasingly recruiting and enrolling community college transfer students (Jenkins \& Fink, 2015; Ma, Baum, Pender, \& Libassi, 2018). In 2016, 1 in 5 community college transfer students enrolled at a private nonprofit college (Jenkins \& Fink, 2015); however, literature remains focused on the public university transfer student, despite the 
growing enrollment of community college transfer students at small, private universities. Moreover, attending a small, private, nonprofit university means a community college transfer student faces unique challenges that have ultimately been unexplored (Rios, 2010; Townsend \& Wilson, 2009). This study focused on the faculty perception of the community college transfer student experience at a small, private university, which provides a unique contribution to current transfer scholarship. To provide a new, unexplored lens of inquiry, faculty were selected as interviewees for this single-site ethnographic, qualitative study. Faculty not only provided an unexplored perception, but were also able to articulate an inside view of university policy, as well as compare the community college transfer student experience to observations of other student types. The research questions and interview protocol focused on three areas: the community college transfer student experience, university programs and policies related to community college transfer students, and a comparison between community college transfers and other student types. Data indicated the community college transfer student experiences were not only different, but often lacked academic affordances given to traditional, "native" students. Native students were defined as those attending the university for the first time without any prior post-secondary education. These findings helped develop recommendations for further research as well as transfer policy implications.

\section{Literature Review}

The community college sector of higher education is significant. Community colleges are comprised of $46 \%$ of all United States undergraduates, $41 \%$ of first-time freshman, $53 \%$ of first-generation students, $56 \%$ of single parents, $48 \%$ of veterans, and $51 \%$ of students with disabilities (Phillippe, 2015). Although this sector represents a large part of higher education, too few of these students graduate after transferring to a different institution. Monaghan and Attewell (2015) reported the community college transfer six-year graduation rate was $25 \%$ compared to the traditional student rate of $46 \%$. Although researchers have shown this gap is closing, community college transfer students are not graduating at the same rate as their native counterparts (Monaghan \& Attewell, 2015). Further, Jenkins and Fink (2016) reported that community college transfer students attending 
public institutions were $10 \%$ more likely to graduate over a six-year period than those attending private nonprofit schools. This is surprising considering four-year private nonprofit institutions overall have a higher graduation rate than public institutions (NCES, 2016). Researchers have also indicated that the rate at which community college transfer students select to attend nonprofit, private institutions might be increasing. In 2005, Romano and Wisniewski found that $18 \%$ of community college transfers attended nonprofit, private institutions; whereas in 2016, Jenkins and Fink found the rate to be closer to 1 in 5 , or $19 \%$.

Many researchers have attempted to explore the differences in graduation rates between native students and community college transfers; however, despite the lower graduation rates at private nonprofit colleges (Jenkins \& Fink, 2016), the community college transfer student experience at private colleges remains absent from the literature (Townsend \& Wilson, 2009). Researchers in the public sector have often identified barriers to overall student success for community college transfer students (Ellis, 2013; Gerhardt \& Ackerman, 2014; Harrison, 1999; Owens, 2010; Schmitigal, 2010; Wilson, 2014). They found community college transfer students are often challenged by the difficulty of transitioning between the two institutional systems (Ellis, 2013; Gerhardt \& Ackerman, 2014; Harrison, 1999; Owens, 2010; Schmitigal, 2010; Wilson, 2014), as well as by a reported loss of credits post-transfer (Ellis, 2013; Gerhardt \& Ackerman, 2014; Harrison, 1999; Owens, 2010). The reported loss of credits is concerning considering Doyle (2006) reported students were $40 \%$ more likely to obtain a degree within six years if they did not lose credits post-transfer. Researchers also reported barriers to academic success (defined as GPA, graduation rate, or retention rate) for community college transfer students post-transfer: feelings of being disconnected from campus (Chrystal, Gansemer-Topf, \& Laanan, 2013; Harrison, 1999; Owens, 2010), transfer shock (Chrystal et al., 2013; Schmitigal, 2010), and difficulties building relationships with faculty (Townsend \& Wilson, 2009). Overall, the literature presents challenges faced by community college transfer students; however, each of these researchers limited the scope of their research to the public sector of higher education.

Although the majority of researchers studying community college transfer experience conducted their research within the public institutional 
context, Rios' (2010) research uniquely focused on students' perceptions at a private college. Students were interviewed during their second year and asked to reflect on the transfer experience. They reported choosing to attend the private university for the following reasons: "location, small class size, personal attention, strong academic programs, support services, and caring professors and staff" (p. 78). Overall, Rios (2010) presented the following factors as the most prevalent to the participants' baccalaureate attainment at the private university: faculty relationships, academic support, and being engaged with peers. Rios (2010) also highlighted the increased need for researchers to consider the unique experiences community college transfer students have within the private university. Others have also called for more research within small, master's-level universities,

Community college transfers to small, teaching-oriented 4-year colleges or master's-level institutions may face different issues in terms of their institutional social and academic integration. Little is known about what they may face in such institutions because the research on community college transfers almost invariably looks at transfers to research universities (Townsend \& Wilson, 2009, p. 419). The student description of the community college transfer experience has been well researched (Chrystal et al., 2013; Ellis, 2013; Gerhardt \& Ackerman, 2014; Harrison, 1999; Owens, 2010; Rios, 2010; Schmitigal, 2010; Wilson, 2014); far less is known from the faculty perspective. Faculty are not only the keepers of curriculum and the assessment of student learning, but they arguably observe first-hand the academic experience of students more than anyone working in higher education. Unfortunately, the faculty perception of student experience is almost completely absent from community college transfer scholarship; however, one researcher published a study in 2014 which interviewed faculty at a public university and compared the interview data to the academic outcomes (GPA) of native and community college transfer students; data were tracked over a five-year period using a matched-pair analysis (Castellino, 2014). Using the interview data, Castellino identified the following salient themes across interviews: articulation agreements causing a perception of student frustration, academic quality viewed lower at community colleges, differences between community college and baccalaureate faculty, perceived challenges for students adjusting post- 
transfer, and commonly described community college transfer student characteristics. This research illustrates the faculty perception as a unique perspective on transfer experience, as well as presents implications to policies impacting community college transfer integration and academic success. Castellino's research further supports a need for more information on the faculty perception of community college transfer student experience, particularly using other kinds of qualitative design and in other institutional contexts.

In summary, the community college transfer student experience at a small private university is absent from the literature and therefore, private universities are left unable to improve institutional effectiveness and properly serve these students. Moreover, the literature remains focused on understanding the integration of the community college transfer from the student's perspective. The study presented in this paper provides a unique contribution to community college transfer research by presenting an understanding within the private university context from the faculty perspective, giving light to both transfer policy and student experience previously unexplored.

\section{Research Questions}

The study took place within a small, private, nonprofit, masters-level university in the Southeastern United States. The following research questions guided this study:

1. How do full-time faculty describe the community college transfer student experience?

2. How do full-time faculty describe community college transfer students' interactions and experiences with university programs and policies?

3. How do full-time faculty perceive the community college transfer student experience when compared to other students?

\section{Methodological Approach}

To better understand the community college transfer student experience, community college transfer policy, and the comparison of community college students to other student types, twelve faculty at a small, private nonprofit 
university were interviewed for a minimum of one hour to a maximum of ninety minutes. The topic of inquiry situated faculty participants and their experiences with the university and its students at the center of the research. A focus on the personal and lived experiences of the faculty made it appropriate to conduct the investigation using qualitative methods, and more specifically, an ethnographic interview design (Roulston, 2010). This approach was selected due to the nature of the research questions and the unit of analysis: full-time faculty at a small, private, nonprofit university. The study was ethnographic in nature, using a cultural lens to interpret interview data (Roulston, 2010) at a small, private university; this developed a description of the faculty participant's experience within the university and with its students. An ethnographic interview study, similar to an ethnography, was used to "explore the meanings that people ascribe to actions and events in their cultural worlds, expressed in their own language" (Roulston, 2010, p. 19). Using an ethnographic interview study design allowed the researcher to develop findings that fully and deeply answered the guiding research questions.

\section{Research Site}

The researcher gave the study site a pseudonym, Sellers University, a small, private, nonprofit, masters-level university in the Southeast. To ensure the participants provided information-rich data, purposeful sampling (Patton, 2015) was used to identify the appropriate university. Sellers University was selected due to having a significant percentage of community college transfer students. According to the university's office of institutional research, in 2015, over $40 \%$ of the student body were transfer students and over half $(50.7 \%)$ of these students came from community colleges. Although the percentage of students at private universities from community colleges is unknown, approximately 1 in 5, or 18\%-19\% of community college transfer students in the United States attend private nonprofit schools (Jenkins \& Fink, 2016; Romano \& Wisniewski, 2005). The considerable number of community college transfer students at Sellers University made it an information-rich study site.

Sellers University was located in an urban community and held religious affiliations. The university was moderately selective, with both undergraduate and masters-level graduate students, totaling just over 2,300 students in 
2016. Sellers University had a diverse student body and was recognized by the federal government as a Title III school. This designation indicated the university served higher-than-average rates of underserved populations, including minorities and low socioeconomic status students. In 2016, just over a quarter of those attending received the Pell Grant and over $40 \%$ identified as a race other than white. The faculty at Sellers University had somewhat different demographics from the students. In 2016, Seller's institutional research office reported $23 \%$ nonwhite and $66 \%$ female full-time faculty.

Undergraduate students were admitted to Sellers University in one of two classifications: post-traditional or traditional. According to the office of institutional research, in 2016 community college transfer students at Sellers University were almost exclusively classified as post-traditional students. This is important due to the differences in university policy and the application of these differences to the study's findings. Findings discussed later suggested that some of the policy differences based on these classifications may have created academic inequity between the two student groups. Community college transfer students, as well as all post-traditional students, received different tuition, services, processes, and procedures than native students. Both groups of students took the same classes with the same professors, but in many other aspects of their academic career interacted with the university differently. Community college transfer students received fewer services at Sellers University in exchange for a lower tuition rate. According to the university's website, in 2017, a community college transfer student paid a reduced tuition rate that was $\$ 279-\$ 423$ per credit hour less than the traditional student rate. In exchange, they received fewer university services. The following offices and services were not available to these community college transfer students: student activities, student government, fraternity and sorority life, clubs and organizations, and health and wellness offices. There were areas of campus where each of these student groups had parallel experiences, meaning the services were offered to both groups, only through different offices. The following services were available to both student types but operated separately from one another: admissions, academic advising, and student orientation. All other offices and services at Sellers University, such as financial aid or dining services, served both student groups.

The different pathways and policies for community college transfer 
students and traditional students at Sellers University were relevant to the study's findings. Discussed later, faculty described many of these unique pathways and services creating an inequitable academic experience for community college transfer students. These findings, developed using specific data collection and detailed analysis, were used to present suggestions for academic policy review and future research.

\section{Data Collection \& Analysis}

Faculty were individually interviewed by the researcher using a semistructured interview protocol. Interviews took place over the summer of 2016, with the exception of two interviews conducted during the pilot study in fall of 2015. Each interview took a minimum of one hour, with the longest interview ending at eighty-six minutes. Twelve faculty were selected for participation using two sampling models: criterion sampling and snowball sampling (Patton, 2015). Faculty selected met the following criteria: full-time status and five or more years of teaching experience at Sellers University. These criteria assured the participants had a significant amount of experience at the institution, as well as experience teaching community college transfer students. The years of teaching experience the faculty had ranged from five to twenty-seven years. Two-thirds of the faculty interviewed were tenured. Twelve faculty were contacted and all twelve participated, three males and nine females; five participants self-identified as racial minorities. Of those interviewed, nine of the twelve faculty held terminal degrees in their respective disciplines. Eight departments were represented: nursing, communications, business, human service studies, psychology, languages, mathematics, and kinesiology. These did not provide comprehensive representation of all disciplines offered at Sellers University; however, the departments did provide diverse perspectives from across each of the larger academic units. The university did not formally notify faculty of which students in their classes were community college transfer students; therefore, the interview protocol asked faculty if they knew which of their students came from community colleges. All of those interviewed indicated they knew which of their students were community college transfers, yet reported gaining this information in different ways, such as first day of class introductions or individual conversations with students. 
The interview protocol and questions were developed during the pilot study in 2015. The pilot interviews helped inform and alter the larger study, which was conducted in 2016. The semi-structured protocol allowed the researcher to ask follow-up questions and for participants to share information they felt applied to the researcher's guiding questions. Adopting an ethnographic approach meant the researcher focused both the formulated interview questions as well as probing questions to be centered upon the culture of a small, private university. Interviews were recorded, transcribed, and coded using thematic analysis. Participants were then given the transcriptions for review prior to coding; these were altered based on participant feedback using member checking (Creswell, 2009; Lather, 1986). A thematic analysis (Glesne, 2011; Saldaña, 2013) was used to analyze the data. Data were first coded using descriptive and in vivo codes. Other forms of coding appropriate for an emic design were also used; for example, versus and emotion coding were both utilized. Once saliency was developed, subcategories were developed into categories, and categories into themes (Glesne, 2011; Saldaña, 2013). The many rounds of coding and the use of multiple coding methods all contributed to the reliability of the thematic analysis (Glesne, 2011).

\section{Validity, Reliability, and Trustworthiness}

Qualitative researchers often seek to provide transparency as a means to gain the trust of the reader, fully accepting subjectivity within the research process and findings. However, positivist quantitative researchers seek to find a single objective truth through means of measurable inquiry, such as statistical analysis. These associations to validity present epistemological tensions between these methods of inquiry, specifically, the difference of what can be known by the researcher. In this qualitative study, the researcher did not seek to find an objective truth but developed methods and means of inquiry to achieve transparency and therefore, trustworthiness and validity of the study's findings. The following tested qualitative practices were used to ensure validity, reliability, and trustworthiness of the research: field notes (Saldaña, 2013), analytic memos (Creswell, 2009; Saldaña, 2013), reflexivity (Denzin \& Lincoln, 2011), and the use of a codebook (Saldaña, 2013), all of which were employed throughout the research process. 
Lather (1986), suggested that qualitative researchers "construct research designs that push us toward becoming vigorously self-aware" (p. 66), to develop trustworthiness and validity in their work. One of the ways this practice was employed throughout this study was the use of reflexivity, defined as "the process of reflecting critically on the self as researcher" (Denzin \& Lincoln, 2011, p. 124). Analytic memos were used to document the researcher's reflections of self and process, as well as to document the researcher's interpretations of the data, each strengthening the trustworthiness, validity, and reliability of the data (Saldaña, 2013). In addition to reflective narrative, tables were also used in analytic memos. Tables helped organize the in vivo and descriptive data, allowing the researcher to understand and recall where categories and themes later came from. Once categories proved salient across interviews, memos were again used similarly to discuss and describe themes. This was key to building transparency in the thematic process (Creswell, 2009).

\section{Positionality \& Epistemic Orientation}

Although subjectivity is inevitable in research, researcher bias should be avoided at all costs. Researchers' positionality, as well as ontological and epistemological perspectives, can influence their work (Grix, 2002), and therefore, it is important for them to be articulated. Experiences, interactions, and foundational beliefs help construct a researcher's reality (ontology) and how one comes to know their reality (epistemology) (Grix, 2002). The researcher for this study was herself a faculty member at Sellers University; however, she was not a participant, nor was the study an autoethnography (Muncey, 2010); therefore, it is important to describe, given the positionality of the researcher, the methods employed to reduce researcher bias. The following tested methods were used within the context of this study: systematized reflexivity (Lather, 1986); face validity (Lather, 1986) through the application of member checking (Saldaña, 2013); and catalytic validity, or "the degree to which the research process re-orients, focuses, and energizes participants" (Lather, 1986, p. 67). These were each employed using different applications of qualitative methods, however, the most important of these was integrated critical reflection, or systemized reflexivity (Denzin \& Lincoln, 2011). Employing these, as well as the other qualitative methods mentioned earlier, helped assert the trustworthiness of the study's findings. 


\section{Findings}

Faculty interview data were coded and thematically analyzed to reveal dominant themes and subsidiary themes outlined in Table 1. The following salient themes emerged: systematically distinct experiences for community college transfer students, limited access to signature programs for community college transfer students, and the unmet needs of community college transfer students. These findings are of particular significance due to the focused university context of a small, private university. Like any qualitative findings, these themes are not generalizable to other experiences, and may not apply to another institution, nor is it known whether these observations of policy and practice are found at other private institutions. However, within the findings of this study, faculty viewed practices and policies at Sellers University as disadvantaging community college transfer students. The following is a description of each of the themes.

\section{Table 1. Themes and Subsidary Themes}

\section{Themes}

Systematically distinct experiences for community college transfer students

Limited access to signature programs

The unmet needs of community college transfer students

\section{Subsidary Themes}

- the loss of course credits and GPA upon transfer

- lack of time at Sellers University

- academic advising

- study abroad

- academic support

- less contact with faculty leading to fewer out-of-class experiences

- unique needs of community college transfer students

- Sellers University being focused on recruiting and retaining a student for 4 years

- community college transfer student being absent from university materials 


\section{Systematically Distinct Experiences for Community College Transfer Students}

The faculty perceived the culture, many systems, and various procedures to be advantaging traditional undergraduate students and disadvantaging community college transfer students. The ways in which the faculty described the students being disadvantaged ranged, but all of those interviewed saw these students facing obstacles, sometimes created by the university, to overcome that other students did not face. The following subsidiary themes emerged: the loss of course credits and GPA upon transfer, lack of time at Sellers University, and an academic advising model that distanced students from faculty.

A common problem reported by transfer students is the loss of course credits after transfer (Ellis, 2013; Gerhardt \& Ackerman, 2014; Harrison, 1999; Owens, 2010). This can often be attributed to a lack of connection or formalized articulation between the four-year college and the community college. Findings from this study suggest this was a potential problem at Sellers University. One interviewee believed the constraints of the campus size, as well as the lack of formalized connections to the community college system afforded to public campuses, meant that Sellers lacked the ability to mitigate transfer credit problems. Another faculty member specifically described it taking a community college transfer student longer to graduate due to loss of transfer credits,

She lost a lot of credit, so it was really frustrating. If she hadn't been running, I'm not sure she would have stayed because it's a long way

from home. It took her a lot longer to graduate than a student that didn't transfer.

This faculty member, along with most other participants, felt that a community college transfer student took more classes than traditional students, yet earned the same degree, potentially creating an inequitable academic experience.

According to faculty participants, another consequence of transferring to Sellers University was the lack of grade point average (GPA) at the university. When students transferred, they lost their community college GPA. The classes themselves transferred, but not the grades. For some transfer students this could be beneficial; however, the faculty described it as a hardship. One 
interviewee described the loss of the transfer GPA making it harder for a community college transfer student to get a good internship because they did not have an established GPA, which hurt a strong student's chances at getting a competitive internship. He says, "even if they have a strong GPA, employers want to see more than one or two semesters, so employers are more likely to select students with longer academic history at the university." He viewed this as an unfair consequence of the transfer process for community college transfer students within a campus culture where internships were critical to job placement upon graduation.

Faculty described Sellers University as having a "tight-knit" culture, where, unlike other institutional types, students had more chances to collaborate with faculty on independent research, hold leadership roles on campus, participate in internships, or engage in opportunities like participating in a theater production. Faculty were concerned that by not having more time at the university, community college transfers could not take advantage of the opportunities a small university culture had to offer, opportunities that make a small, private campus unique and may have attracted the students to the university in the first place. Rios (2010) indicated that small class size and personal attention are key reasons students select to attend small private schools. Faculty interviewed believed that community college transfer students missed experiences afforded to those with more academic history at the university. One interviewee stated,

Because they [community college transfers] are here such a short amount of time, they get to senior year and have regrets, "I wish I would have known that" or "I wish I would have been told that" or "I wish I would have been able, I wish someone would have pushed me to do that."

Faculty described other incidents when students were excluded from opportunities due to a lack of time at Sellers University. For example, applying to student research programs or leadership positions were also often viewed as out of reach. Interview data described community college transfer students being not only less likely to participate in these kinds of experiences but less likely to be aware they existed. One interviewee stated that spring transfers were particularly disadvantaged due to the timing of their transfer, "elected positions are complete, teams are fielded, and play auditions are over, spring 
transfers miss a lot." Although the faculty viewed this as a disadvantage, it was unknown whether these were opportunities that community college transfer students would want to participate in. However, it is well known by researchers that community college transfer students report difficulty transitioning between the two institutional systems (Ellis, 2013; Gerhardt \& Ackerman, 2014; Harrison, 1999; Owens, 2010; Schmitigal, 2010; Wilson, 2014) and therefore, giving community college students many opportunities to connect to a campus is important.

The subsidiary theme of academic advising was the most prominent and significant of themes through the coding and analysis. As stated previously, community college transfer students were advised all four years by a professional staff advisor, whereas traditional undergraduates were advised by the full-time faculty within the student's major field of study. The faculty interviewees described this separation of advising as a disadvantage for those advised by professional staff advisors. Interview data indicated that this not only limited the students' access to faculty, but also created greater likelihood for advising error.

Faculty perceived the advising model creating distance between community college transfer students and faculty. Specifically, faculty often made comments like the following, "they don't have an advisor that's a faculty member and that concerns them [the community college student]" or "they don't get good advising" which "leads to feeling disconnected from the university and their faculty." Students were viewed by the faculty as being reluctant to approach them, and the advising model was a systematic way the university's policy created distance between faculty and transfer students. Faculty saw this as withholding an opportunity to build relationships with the faculty in their discipline, which according to Tinto's theory $(1993,1975)$, as well as community college transfer researchers (D'Amico, Dika, Elling, Algozzine, and Ginn, 2014; Townsend \& Wilson, 2009), a student's experience in the academic system, and therefore faculty relationships, are critical to community college transfer student retention.

One faculty interviewee viewed this as a concern not only for the student's time at Sellers University, but beyond graduation, "as they get into their major they really need somebody in their major [advising them]. Because not only do they need advising for what classes to take but that's one 
way conversations happen about career goals." Others echoed the value of the faculty/student relationship beyond the classroom, noting connections to the discipline that could best be provided by a faculty member within the department, opportunities such as honors societies, civic engagement within the field, faculty reference letters, or potential collaboration with faculty on research projects. Interviewees felt that these opportunities frequently resulted from meeting one-on-one with faculty in the student's major, often through advising.

In addition to the missed opportunity of building faculty/student relationships through advising, the faculty also viewed the staff advisors as inadequate in their ability to accurately advise. According to the faculty, each staff advisor was asked to advise many different disciplines, as well as many student advisees; due to the staff advisors having so many disciplines and advisees, faculty observed advising mistakes. As a result, faculty felt students were not getting "good advising" and students were more likely to be "misadvised" by staff.

Faculty provided examples of community college transfer students who came to them for advising despite being assigned a professional staff advisor. Faculty representing different departments described frustration because so many community college students came to them for advising help even though the students were not their advisees. One faculty member stated,

I advise a lot of them [community college transfers] off the books. In fact, this past spring I got a call from one of my advisees saying, would you talk to this guy because he's not getting a lot of good help and he's confused. So, he's learning a new system and we were able to get on the phone and talk, and it did him a lot of good. Yeah, I do a lot of off-the-books advising for them.

Faculty were frustrated by an inability to access files and transcripts to help students,

The best ones [community college transfers] come and sit down and chat anyway, even though I do not have access to their transcripts, which is hard. They often want to get a feel for where they are going from here, which is perfectly fine.

Another described the following experience,

Well, they [community college transfers] don't feel that people care 
about them as much. Okay, they don't feel like they get the advising that TUGs [traditional undergraduates] get. They don't have an advisor that's a faculty member and that concerns them, and I always say you know "Come in anytime, we'll talk about this." They do... but they are so much more likely to be misadvised, that's a huge issue... they're often like, "why can't I take this?" and you know nobody's advised them in the order of the classes, which if you can only take night classes that can get pretty, you know tight.

Overall, faculty wanted to help community college transfer students, particularly because they observed these students being negatively affected by the loss of transfer credits and the lack of time at Sellers University. As previously stated, faculty were the most concerned about the academic advising model creating disparity, giving faculty less out-of-class contact with community college transfers. However, it is important to note that it was unknown if these experiences and perception of disparity would be shared by the community college transfer students themselves, nor if the advising model, and its disparities, are similar at other institutions.

Limited Access to Signature Programs

According to the university website, "study abroad is a core part of the Sellers University experience." According to the Director of the Center for International Education, in 2016, "78\% of our traditional undergraduates are studying abroad before they graduate." This is a prideful statement about a signature program at Sellers University, however, faculty suggested that the study abroad program at Sellers University was not as readily available to a community college transfer student.

Faculty agreed that study abroad was something all students benefited from, yet was underutilized by community college transfers. One faculty member gave an example,

With all that Sellers University has to offer, he was the only JC [junior college] kid to ever ask me about the international program. He said, will I qualify? I said, yep, but you will have to pay for it. Only JC kid to ever ask me about that.

Sellers University believed in the academic study abroad program so deeply, it was part of a traditional undergraduate's tuition, which, according to the faculty interviewed, was not true for the community college transfer student. 
Traditional students paid a higher tuition rate and as part of this higher rate, had funds available to participant in an academic course and short-term study abroad program at little to no additional cost. Community college transfers paid a reduced tuition rate, leaving them without funds for an international experience. It was unknown by the researchers if community college transfer students desired to participate; however, it was clearly perceived by the faculty as an institutional mechanism for disparity, withholding equitable access to a signature program for community college transfer students.

Another signature experience described by the faculty was tutoring services. An interviewee shared that community college transfer students were more likely to need tutors at the 300 and 400 level. Upper-level tutors were not available, and those that were could only meet during evening hours. Another interviewee shared how community college students are reluctant to seek tutoring and academic support, “they don't feel like they can ask for help or they don't think they have time, or they don't think anyone is available for them when they get off work." Other faculty described a concern for tutoring services not being offered during evening and weekend hours - times they viewed as important for community college transfer students.

Other signature experiences were described by the faculty as out of reach for many community college transfer students, or underutilized due to the students being unaware of services. Faculty felt they had less opportunity to connect community college transfer students with discipline-specific honor societies, internship opportunities, symposiums, guest speakers, and discipline-specific conferences. Faculty believed community college transfers did not participate in these experiences as frequently as their traditional counterparts, a problem often attributed to having less interaction with faculty outside of the classroom. This is concerning, particularly considering the importance of faculty/student relationships for community college transfers (Townsend \& Wilson, 2009), and its connection to retention and graduation rates (Tinto, 1993, 1975).

\section{The Unmet Needs of the Community College Transfer Student}

This theme described the faculty perception of the community college transfer student having unique needs and, due to the university's primary 
focus being the traditional undergraduate, these needs being unmet. The following subsidiary themes emerged: unique needs of the community college transfer students; Sellers University being focused on recruiting and retaining a student for four years; and an absence of community college transfer students, and their needs, from marketing materials and websites.

Faculty saw community college transfer students as having different needs from other student types. Faculty gave examples of students missing class to care for a sick child or balancing the responsibilities of working and taking classes, experiences they did not believe were likely to be shared by traditional, native students. Faculty commonly made the following comments when asked to compare the community college transfer student to other student types, So often they [community college transfers] may have to work quite a bit, whereas a traditional student may not. I do tend to see ones that I know working quite a bit more. They may also have family obligations that a traditional student, younger traditional student, doesn't necessarily have.

The interview data illustrated community college transfer students needing evening and flexible classes and services, as well as having a much greater emphasis on academic experiences, and less need to engage with social opportunities. Often due to work or family obligations, faculty described students as less interested in social clubs or events, but interested in participating in "academic stuff," examples of which were: faculty/student research collaborations, internships, or honors societies. These findings support recent community college transfer student literature, suggesting that community college transfer students need a greater emphasis on the academic experience. Building upon Tinto's Attrition Theory (1993), researchers have indicated that the social system was less important for community college transfer students, and a greater emphasis should be placed on the academic system (inside and outside of the classroom), particularly when considering outcomes such as student retention (D’Amico, Dika, Elling, Algozzine, and Ginn, 2014; Townsend \& Wilson, 2009).

The second subsidiary theme developed in the interview data was Sellers University being focused on recruiting and retaining a student for four years. This was often coded as the campus culture privileging the dominant student population: traditional, native students. Some interviewees described this generally, whereas others more explicitly stated the university was clearly 
motivated to primarily serve the traditional student. One interviewee detailed why she believed Sellers University was not as motived to focus on transfer students overall, "they [the university administration] are really are not as interested in retaining transfer students, what they want to retain are firstyear students, because we get four years of tuition out of them." Others had similar feelings that Sellers University was set up to serve traditional students, community college transfer students were often an afterthought. One faculty member shared concern that not only Sellers University as a whole, but her fellow faculty were more focused on traditional students, she said, "I heard in a faculty meeting a faculty member say, 'well, the heart and soul of this institution is our TUGs [traditional undergraduates]' - I wanted to say, 'there's a lot of heart and soul with the transfer students too!'”

Another subsidiary theme was the absence of community college transfer students, and their needs, from the website, admissions, and marketing materials. In a comment about the Sellers University website one faculty interviewee stated, The transfer students, you know you don't usually see anything on there of "Hey, I transferred to Sellers University from Northwest Community College and this is great." Oh we don't want to talk about that, we want to talk about that you're going to go here all four years.

Another interviewee believed Sellers University should tell the story of more diverse populations,

I think income level wise, racial wise, ethnic group... I mean there's a lot of community college transfers that are immigrants too, you know that population is here, and we don't think of any of that as a Sellers University student, you know and certainly, the community does not think of that. They still think of the white girls, you know that are 18 years old. I think we should market to that population [the community college transfer] and realize that population, what they go on to do is just amazing.

According to one interviewee, the university website lacked the process of how to transfer from a community college, as well as articulation agreements. Articulation agreements are used to recruit students locally, and, according to the office of institutional research, over $70 \%$ of Sellers University students came from the Southeast, meaning local recruitment would be important and these agreements would be utilized by community college transfers. 
Universities have used articulation to formalize the transfer process for community college students; however, recent literature suggests that even when agreements are available, students find them difficult to use and unreadable (Taylor, 2019). According to the interviewee, not only the articulation agreements, but also the process to transfer credits, could not be accessed without contacting the registrar's office directly and even then, much of the information was nowhere to be found. However, the process of how to transfer college credits earned while in high school (lateral entry) was outlined on the website. If accurate, this is an example of the website being designed for the traditional student and not properly serving the community college transfer students' needs.

In summary, the faculty interviewees painted a complex picture of the community college transfer experience at Sellers University. Overall, the faculty spoke highly of the institution they were a part of, but also expressed concern for how the culture and academic policy were structurally disadvantaging the community college transfer student. It is appropriate to note that all the faculty's concerns centered on out-of-class experiences (academic advising, student/faculty research, study abroad, honor societies, etc.); however, faculty viewed these experiences as academic in nature. Academic experiences should not only be available to all students but equitably accessible. Findings presented here developed a description of the faculty perception at a small, private nonprofit university. Due to the lack of study and literature within this context, it was unknown if these results would present similarly at other small private universities. However, the findings did indicate the potential for disparity in academic experience and a need for campuses to consider coordinated efforts to ensure an equitable academic experience across student types at small, private nonprofit institutions.

\section{Implications to Policy and Practice}

Universities should provide an equitable academic experience for all students. This study suggests that institutional practices, such as creating unique policies for community college transfer students, may disadvantage the student's academic experience. Offering students options to select nonacademic services such as housing, social engagement, or healthcare services is a cost-effective way for universities to offer tailored services for a 
reduction in tuition; however, this study illustrates the need for universities to ensure that by providing cost-efficient options they are not affecting the university's ability to offer an equitable academic experience, nor the students' ability to have equal access to programs afforded them. Using the findings from this study, the following are actionable recommendations for four-year campuses.

Campus administrators should evaluate how different student groups interact with offices and policies across campus. Using a tested organizational analysis model, campus agents should identify how student pathways both advantage or disadvantage the student experience. This analysis should be focused on ensuring an equitable academic experience for all student types.

Academic advising should be a successful part of all students' academic experience and is a key part of a student's academic success, both during their integration and throughout their academic career. All students within a university should be given the same access to faculty and quality advising. For example, if faculty advise traditional undergraduates, they should also advise community college transfer students.

Campus administration should review and change university materials to ensure equity and access for all student types. This should go well beyond ensuring students of color or students of different ages are presented on marketing materials. For example, university articulation agreements should be easily accessible and digestible for incoming community college transfer students.

Campuses should build systematic opportunities for all students to develop relationships with faculty. According to Tinto's Attrition Theory $(1975,1993)$ student relationships with faculty are a key element of academic integration, which is important in reducing student attrition and increasing student success. Findings from this research suggested that community college transfer students were getting fewer out-of-class opportunities to build relationships with faculty. Therefore, creating equitable opportunities for all students to make connections with faculty can be a catalyst to academic success and student retention for all. 


\section{Recommendations for Research}

This study's findings are significant for researchers in the fields of equity in higher education and community college transfer success, as well as institutional policy and administrative practices. Faculty described a complicated issue of inequity for community college transfer students that is both directly connected to student success and administrative practice. Researchers can build upon this study's findings using the following recommendations for research:

Qualitative inquiry using document analysis is recommended. The faculty interviewed described not only programs like academic advising, but also institutional processes creating environmental disparities. These perceptions should be used to conduct a document analysis investigating the potential for structural bias against community college transfer students or isolated student experiences at various institutional types. Documents such as university websites, catalogs, admissions information for community college transfers, and other policies could be researched using a directed analysis.

Mixed methods research to identify connections between student perceptions and outcomes data would provide a deeper description of the phenomena. The scope of the study presented here was limited to the faculty perception of student experience. Little is still known from the student perception within the small private university context. A matched pair analysis of graduation rates, or GPA data, between student types within the small private university context could be compared to the descriptions of student experience collected through interviews or focus groups.

A quantitative survey tool should be used to investigate admissions policies and practices. The study site researched here had very different admission practices for different student populations. Although it is possibly an anomaly, other campuses could be utilizing similar practices with success or dysfunction. Campus administrators should be surveyed to identify the frequency of such practices, and describe their perceived success.

\section{Limitations}

By using a qualitative ethnographic design, a rich description of the faculty perception at a small private university was provided; however, the design of this study also adopted limitations. For example, the scope of 
the study's inquiry did not explore how the students, or others at Sellers University, perceived the community college transfer student experience. Additionally, by only interviewing faculty at one institution, the data were not generalizable, other than to the literature. Therefore, recommendations to policy and research were focused on gathering information and reviewing individual policy and practice. The aim of this study was not to provide knowledge that could be generalized to other institutions, but to inform campus agents of the kinds of perceptions that could be evident and to spark conversation on campuses about the possibility of inequitable transfer policy and culture.

\section{Conclusion}

This study provides a unique contribution to current transfer research and policy by focusing on the community college transfer student experience at a small, private nonprofit university. The findings illustrate how a private campus might create an inequitable academic environment for students through policy. Sellers University used a reduced tuition rate to attract community college transfer students; in exchange, students received reduced or separate services. The researcher's findings suggested these reduced and separate services, such as academic advising, academic support systems, and access to faculty mentorship, created disparities in academic experience. In addition, a cultural and institutionalized focus on the dominant student population (the native student) also played a part in the faculty describing these student experiences as inequitable. Faculty interview data suggested these inequities may have hindered the community college transfer students' academic success. Institutions have a responsibility to create equitable academic environments for all students. Therefore, recommendations such as a review of institutional policies and practices are suggested to explore a deeper understanding of equitability of academic experience for all student types. 


\section{References}

Castellino, L. (2014). Who are community college transfer students?: A view through the faculty lens. Retrieved from Dissertation Abstracts International Section U.S. (742695871).

Chrystal, L. L., Gansemer-Topf, A., \& Laanan, F. S. (2013). Assessing students' transition from community college to a four-year institution. Journal of Assessment and Institutional Effectiveness, 45(1), 3-32.

Creswell, J. W. (2009). Research design: Qualitative, quantitative, and mixed methods approaches. Thousand Oaks, CA: Sage Publications.

D’Amico, M. m., Dika, S., Elling, T., Algozzine, B., \& Ginn, D. (2014). Early integration and other outcomes for community college transfer students. Research In Higher Education, 55(4), 370-399.

Denzin, N. K., \& Lincoln, Y. S. (2011). The Sage handbook of qualitative research. Thousand Oaks: Sage.

Doyle, W. R. (2006). Community college transfers and college graduation. Change, 38(3), 56-58.

Ellis, M. M. (2013). Successful community college transfer students speak out. Community College Journal of Research and Practice, 37(2), 73-84.

Gerhardt, K., \& Ackerman, M. (2014). Postsecondary student mobility from college to University: student expectations and experience. College Quarterly, 17(1). 1-17.

Glesne, C. (2011). Becoming qualitative researchers: an introduction (4th ed.). Boston, MA: Pearson Education, Inc.

Grix, J. (2002). Introducing students to the generic terminology of social research. Politics 22(3), 175-186.

Harrison, P. L. (1999). Transition experiences of community college transfer students: a qualitative study. Retrieved from ProQuest Dissertations \& Theses Global (304532662)

Jenkins, D. \& Fink, J. (2015). What we know about transfer. New York, NY:

Columbia University, Teachers College, Community College Research Center. 
Jenkins, D., \& Fink, J. (2016). Tracking transfer: new measures of institutional and state effectiveness in helping community college students attain bachelor's degrees (January 2016 Report). New York: NY: National Student Clearinghouse Research Center

Lather, P. (1986). Issues of validity in openly ideological research: Between a rock and a soft place. Interchange, 17(4), 63-84.

Ma, J., Baum, S., Pender, M., \& Libassi, C. (2018). Trends in college pricing 2018. New York: The College Board.

Monaghan, D., \& Attewell, P. (2015). The community college route to the bachelor's degree. Educational Evaluation and Policy Analysis, 37(1), 70-91.

Muncey, T. (2010). Creating autoethnographies. Thousand Oaks, CA: Sage.

Owens, K. R. (2010). Community college transfer students' adjustment to a four-year institution: A qualitative analysis. Journal of the First-Year Experience \& Students in Transition, 22(1), 87-128.

Patton, M. Q. (2015). Qualitative research \& evaluation methods: Integrating theory and practice. Thousand Oaks, CA: Sage Publications.

Phillippe, K. (2015). Data points: Who attends community college? (April, 2015). Retrieved from the American Association of Community Colleges website: http://www.aacc.nche.edu/ Publications/ datapoints/Pages/default.aspx

Rios, V. A. (2010). Community college transfer students' reflections of their needs, experiences, and persistence at a private four-year institution (Order No. 3470237). Retrieved from ProQuest Dissertations \& Theses Global (744101234).

Romano, R. M., \& Wisniewski, M. (2005). Tracking community college transfers using national student clearinghouse data. Association for Institutional Research. Retrieved from Eric database (ED512354)

Roulston, K. (2010) Reflective interviewing: A guide to theory and practice. London: Sage Publications Inc.

Saldaña, J. (2013). The coding manual for qualitative researchers (2nd ed.) Los Angeles, CA: Sage Publications. 
Schmitigal, L. (2010). Students' perceptions of baccalaureate completion programs at community colleges: A qualitative study (Order No. 3405545). Available from ProQuest Dissertations \& Theses Global (193735075)

Taylor, Z. (2019). Inarticulate Transfer: Do Community College Students Understand Articulation Agreements? Community College Journal of Research and Practice, 43(1), 65-69.

Tinto, V. (1975). Dropout from higher education: a theoretical synthesis of recent research. Review of Educational Research, 45, 89-125.

Tinto, V. (1993). Leaving college: rethinking the causes and cures of student attrition. ( $2^{\text {nd }}$ Ed.). Chicago, IL: The University of Chicago Press, Ltd.

Townsend, B. K., \& Wilson, K. B. (2009). The academic and social integration of persisting community college transfer students. Journal of College Student Retention: Research, Theory \& Practice, 10(4), 405-423.

U.S. Department of Education, National Center for Education Statistics. (2016). Persistence and attainment of 2011-12 first-time postsecondary students after 3 years. (NCES 2016-401). Retrieved from the National Center for Educational Statistics website: https://nces.ed.gov/ pubsearch/pubsinfo.asp?pubid=2016401

Wilson, D. (2014). Follow me to the baccalaureate: reflections and advice from African American community college transfer student journeys. Community College Enterprise, 20(2), 72-84. 